HETEROCYCLES, Vol. 93, No. 1, 2016, pp. -. (C) 2016 The Japan Institute of Heterocyclic Chemistry Received, 31st August, 2015, Accepted, 17th September, 2015, Published online,

DOI: $10.3987 / C O M-15-S(T) 34$

\title{
CONSTRUCTION OF cis-FUSED HYDRINDANE SKELETON WITH A LACTONE TETHER UTILIZING INTRAMOLECULAR DIELS-ALDER REACTION
}

\section{Shuqiang Yin," Kenji Takai,' Daishiro Minato,' Kenji Sugimoto," Hideki Ohtsu, ${ }^{b}$ Kiyoshi Tsuge, ${ }^{b}$ and Yuji Matsuya ${ }^{a, *}$}

${ }^{\mathrm{a}}$ Graduate School of Medicine and Pharmaceutical Sciences, University of Toyama, 2630 Sugitani, Toyama 930-0194, Japan, b'Graduate School of Science and Engineering, University of Toyama, 3190 Gofuku, Toyama 930-8555, Japan. E-mail: matsuya@pha.u-toyama.ac.jp

\begin{abstract}
Synthetically important, cis-fused hydrindane skeleton having quaternary angular stereogenic centers was selectively furnished by intramolecular Diels-Alder reaction of ester-tethered precursor via endo transition state. The reaction was applicable for a construction of the steroidal BCD ring system with cis-hydrindane framework.
\end{abstract}

Hydrindane skeletons, a 6/5-fused bicyclic system, have been widely found in biologically active compounds, representatively such as a steroidal CD ring. ${ }^{1}$ Many of the naturally occurring steroidal compounds have a trans stereochemistry on the CD ring juncture, and consequently, considerable efforts have been devoted for development of efficient construction methods of trans-hydrindane skeletons. ${ }^{2}$ Among them, an intramolecular Diels-Alder approach has been explored for the predominant formation of the trans-hydrindanes (Scheme 1-a). ${ }^{3}$ In general, this approach preferentially gave the trans-hydrindane skeleton, and only minor cases have been reported for providing the cis-fused hydrindanes. ${ }^{4}$ On the other hand, the intermolecular Diels-Alder reaction between cyclopentenes and dienes are a promising and reliable approach for the formation of cis-hydrindanes due to the inherent stereospecificity of Diels-Alder reactions (Scheme 1-b). ${ }^{5,6}$

(a)

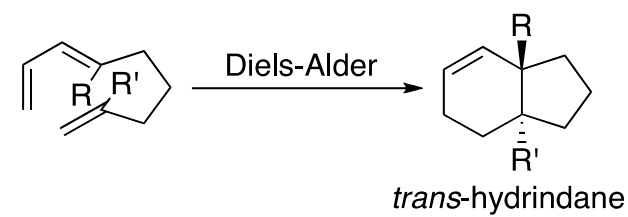

(b)<smiles>C=CC=C</smiles>

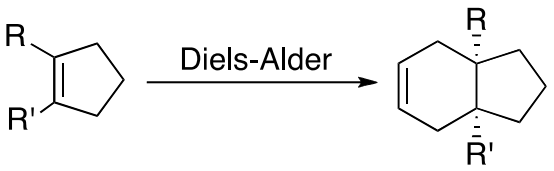
cis-hydrindane

Scheme 1. Reaction modes of Diels-Alder reaction

This paper is dedicated to Professor Lutz F. Tietze on the occasion of his $75^{\text {th }}$ birthday. 
Hydrindanes having a cis stereochemistry have also been an important class of a substructure of bioactive natural compounds. For example, pinguisone showing antifeedant activity is a natural sesquiterpene possessing a furan-fused cis-hydrindane skeleton. ${ }^{7}$ Sarmentogenin and ouabagenin are aglycons of cardiac glycosides rhodexin $\mathrm{A}^{8}$ and ouabain, ${ }^{9}$ respectively, having unusual cis-fused $\mathrm{AB}$ and $\mathrm{CD}$ rings on their steroidal frameworks. Andrastins are meroterpenoids containing the cis-hydrindane substructure, and reported to inhibit the activity of the ras protein farnesyltransferase, thus being a promising lead compound for novel anticancer agents (Figure 1). ${ }^{10}$ All of these natural products commonly possess two quaternary carbons on the ring juncture of the cis-hydrindane. Therefore, use of sterically hindered tetra-substituted cyclopentenes as a dienophile is enforced in the forementioned intermolecular Diels-Alder strategy for the construction of cis-hydrindanes of such natural products. This means that dienes used in this strategy are often limited to sufficiently activated compounds such as Danishefsky's dienes, and this situation is really found in the past literatures. ${ }^{11}$ In this paper, we describe the Diels-Alder reaction between highly electron-deficient tetra-substituted cyclopentene and unactivated dienes taking advantage of the intramolecular fashion using ester-tethered substrates of dienes and dienophiles, leading to a useful scaffold of natural compounds containing the cis-hydrindanes which have quaternary angular carbons.

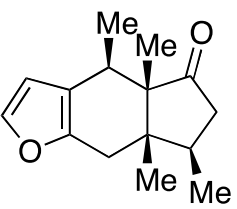

Pinguisone

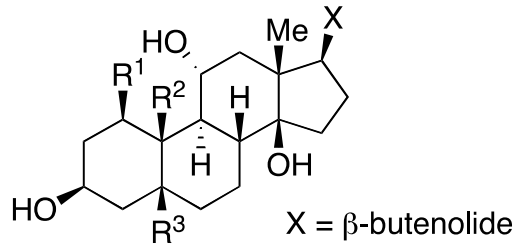

Sarmentogenin $\left(R^{1}=R^{3}=H, R^{2}=M e\right)$ Ouabagenin $\left(\mathrm{R}^{1}=\mathrm{R}^{3}=\mathrm{OH}, \mathrm{R}^{2}=\mathrm{CH}_{2} \mathrm{OH}\right)$

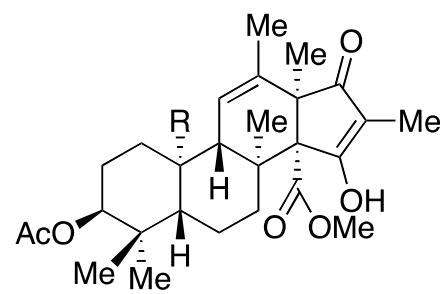

Andrastin $\mathbf{A}(\mathrm{R}=\mathrm{CHO})$, B $\left(\mathrm{R}=\mathrm{CH}_{2} \mathrm{OH}\right), \mathbf{C}(\mathrm{R}=\mathrm{Me})$

Figure 1. Natural compounds containing the cis-hydrindane substructure

Methyl 2-methylcyclopenten-3-one-1-carboxylate (2a) ${ }^{12}$ is considered as a highly activated dienophile for Diels-Alder reaction. However, this compound has never used as a Diels-Alder dienophile with unactivated dienes probably due to steric congestion, although several examples have been reported that similar tetra-substituted cyclopentenone derivatives are conducted to intermolecular Diels-Alder reaction with dienes activated by one or more alkoxy substituents. In regard to the cycloaddition reaction of the compound 2a, photochemical [2+2] addition with allenes is only one example to the best of our knowledge. $^{13}$

In fact, the Diels-Alder reaction of $\mathbf{2 a}(\mathrm{R}=\mathrm{Me})$ with the simple unactivated diene $\mathbf{1}$ did not proceed under thermal conditions in an intermolecular fashion in our hands. We then decided to try the corresponding intramolecular cycloaddition by using the ester-tethered substrate $3{ }^{14}$ which was prepared from the carboxylic acid 2b $(\mathrm{R}=\mathrm{H})$ and 2,4-hexadien-1-ol under dehydrative condensation conditions. 
Gratifyingly, the intramolecular Diels-Alder reaction of the substrate 3 cleanly proceeded at $180{ }^{\circ} \mathrm{C}$ (sealed tube) to give the cis-hydrindane 4 in 91\% yield. The reaction was endo selective (via endo-TS), which was confirmed by the NOE observation experiments (Scheme 2).

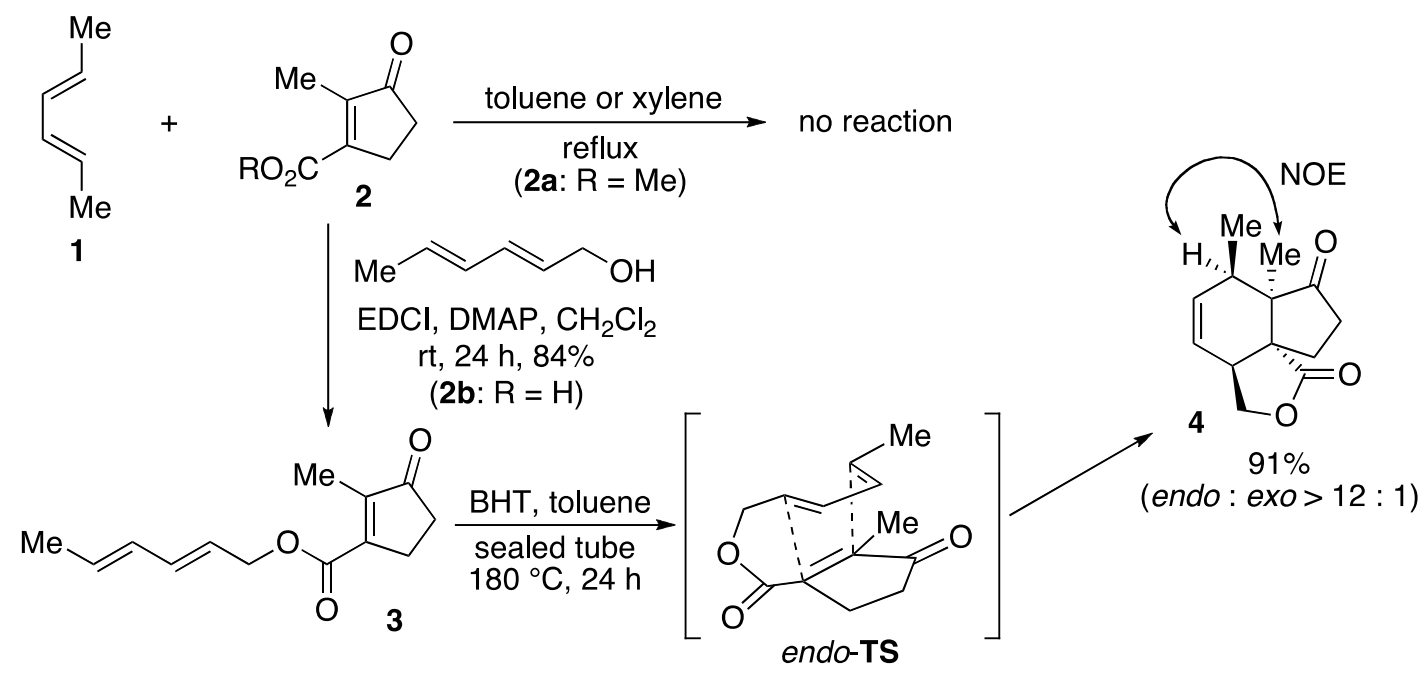

Scheme 2. Successful Diels-Alder reaction for cis-hydrindane

Encouraged by the above results, we applied this strategy for the construction of the steroidal BCD ring system with cis-hydrindane framework. The Diels-Alder substrate 9 was designed for this purpose, and synthesized according to Scheme 3. Commercially available cyclohexanedione 5 was converted to the iso-butyl enol ether $\mathbf{6}$ following the literature method, ${ }^{15}$ and the product $\mathbf{6}$ was allowed to react with trans-propenyl Grignard reagent followed by acidic hydrolysis to afford the dienone 7 in good yield. DIBAL reduction of $\mathbf{7}$ gave the alcohol $\mathbf{8}$, which was subjected to esterification with carboxylic acid $\mathbf{2}$ using EDCI and DMAP to furnish the Diels-Alder substrate 9 in an efficient manner.

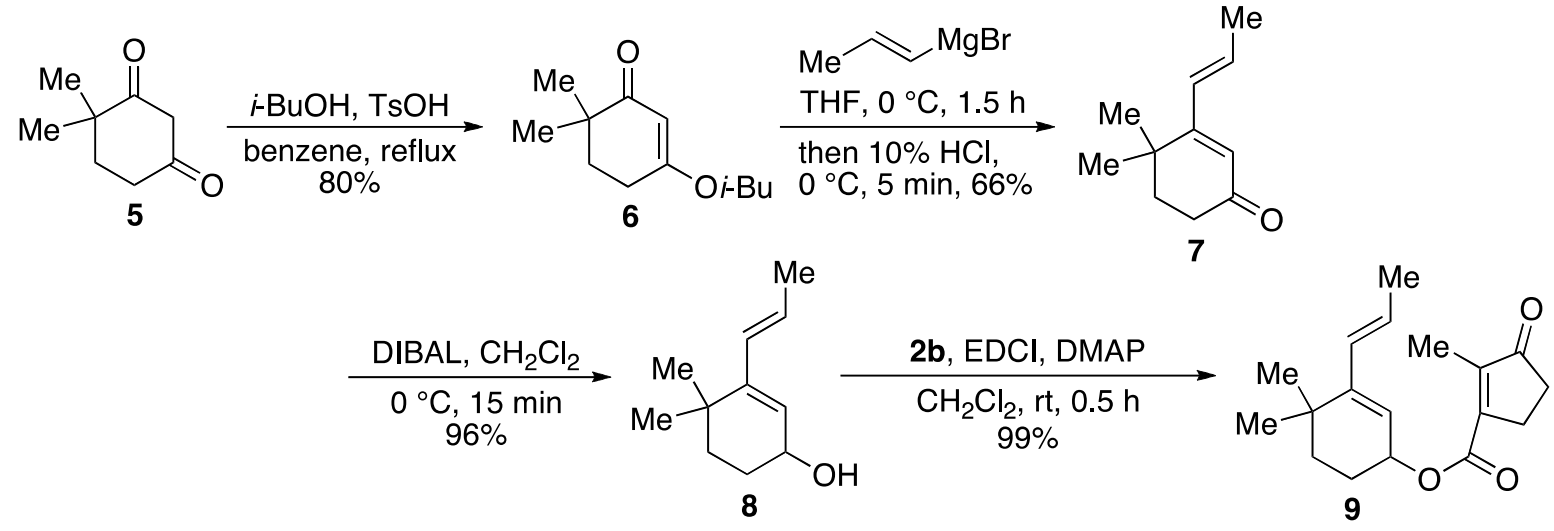

Scheme 3. Preparation of a precursor for steroidal BCD ring system with cis-hydrindane framework 
With the substrate compound $\mathbf{9}$ in hand, we investigated optimal conditions for the intramolecular Diels-Alder reaction to establish the lactone-tethered tricyclic system formation (Table 1). Although the reaction did not proceed under toluene reflux condition (entry 1), the desired cycloadducts were formed in refluxing xylene in low yield (entry 2). Favorably the reaction was largely improved at $145^{\circ} \mathrm{C}$ in a sealed tube to realize 73\% yield, whose endo/exo ratio was 53/20 (entry 3). The reaction was found to be highly susceptible to the temperature, and the yield was decreased at $160{ }^{\circ} \mathrm{C}$ (entry 4) and considerable decomposition was observed in short time at $180{ }^{\circ} \mathrm{C}$ in $o$-dichlorobenzene (entry 5). The stereostructure of the product 10a was unambiguously determined by X-ray crystallography (Figure 2) to be an endo-adduct, which was predominant product via the similar endo transition state in the case of Scheme 2. ${ }^{16}$ Thus, the best condition of the intramolecular Diels-Alder reaction of $\mathbf{9}$ was established, and efficient approach for the tetracyclic framework 10 including the cis-hydrindane and the ester tether was accomplished. These compounds would be versatile scaffolds for bioactive natural compounds containing the cis-hydrindane substructure.

Table 1. Diels-Alder Reaction for steroidal BCD ring with cis-hydrindane framework<smiles>C/C=C/C1=CC(OC(=O)C2=C(C)C(=O)CC2)CCC1(C)C</smiles>

9

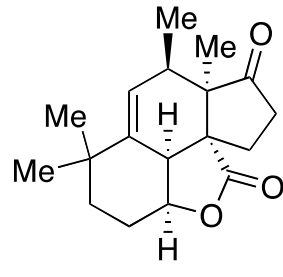

10a (endo)

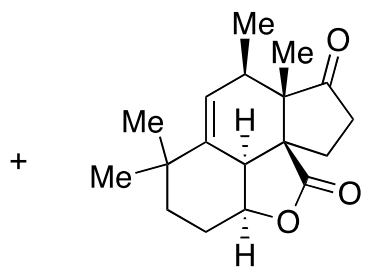

$10 \mathrm{~b}(e x O)$

\begin{tabular}{ccccc}
\hline entry & solvent & temp & time $(\mathrm{h})$ & \% yield (10a/10b) \\
\hline 1 & toluene & reflux & 14 & no reaction \\
2 & xylene & reflux & 18 & $17 / 19$ \\
3 & xylene & $145^{\circ} \mathrm{C}$ (sealed tube) & 18 & $53 / 20$ \\
4 & xylene & $160^{\circ} \mathrm{C}$ (sealed tube) & 18 & $18 / 16$ \\
5 & o-dichlorobenzene & $180^{\circ} \mathrm{C}$ (sealed tube) & 1.5 & complex mixture \\
\hline
\end{tabular}

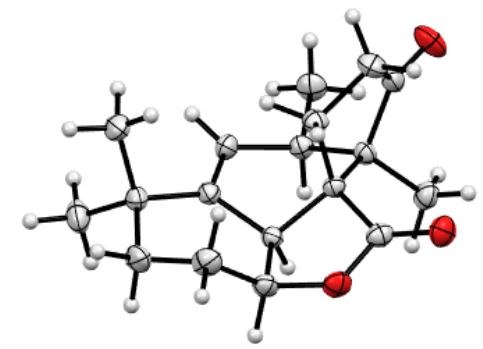

Figure 2. ORTEP drawing of the endo-adduct 10a 
In this paper, we have described the efficient intramolecular Diels-Alder strategy for the cis-hydrindane skeleton construction, between highly congested tetra-substituted cyclopentenone and unactivated dienes using ester-tethered substrates of dienes and dienophiles. These reactions would serve for providing useful scaffolds of various compounds containing the cis-hydrindanes having quaternary angular carbons such as illustrated in Figure 1. Further applications of these reactions for natural product syntheses are now under investigation in our laboratory.

\section{EXPERIMENTAL}

All nonaqueous reactions were carried out under an Ar atmosphere. Reagents were purchased from commercial suppliers and used as received. Anhydrous solvents were prepared by distillation over $\mathrm{CaH}_{2}$, or purchased from commercial suppliers. ${ }^{1} \mathrm{H}$ and ${ }^{13} \mathrm{C}$ NMR spectra were measured on a JEOL ECX 400 or a Varian GEMINI 300 instrument, using $\mathrm{CHCl}_{3}\left(7.26 \mathrm{ppm}\right.$ for $\left.{ }^{1} \mathrm{H}\right)$ and $\mathrm{CDCl}_{3}\left(77.0 \mathrm{ppm}\right.$ for $\left.{ }^{13} \mathrm{C}\right)$ as an internal reference. The following abbreviations are used for spin multiplicity: $\mathrm{s}=$ singlet, $\mathrm{d}=$ doublet, $\mathrm{t}=$ triplet, $\mathrm{q}=$ quartet, $\mathrm{m}=$ multiplet, and br = broad. $J$ values were in hertz. Mass spectra were measured on a JEOL JMS-GCmate II or a JEOL JMS-AX 505 HAD mass spectrometer, and the ionization method was electron impact (EI, $70 \mathrm{eV}$ ). IR spectra were recorded on a JASCO FT/IR-460Plus spectrometer. Column chromatography was carried out by employing Cica Silica Gel 60N (spherical, neutral, 40-50 $\mu \mathrm{m}$ ).

(2E,4E)-Hexadienyl 2-Methyl-3-oxo-cyclopent-1-ene-1-carboxylate (3). To a stirred solution of the carboxylic acid $\mathbf{2 b}$ (440 mg, $3.14 \mathrm{mmol})$ in $\mathrm{CH}_{2} \mathrm{Cl}_{2}(15 \mathrm{~mL})$ were added DMAP (192 mg, $\left.1.57 \mathrm{mmol}\right)$, EDCI (900 mg, $4.70 \mathrm{mmol}$ ), and 2,4-hexadien-1-ol (463 mg, $4.70 \mathrm{mmol}$ ) at room temperature. After stirred for $24 \mathrm{~h}$ at the same temperature, the mixture was concentrated in vacuo. The residue was purified by flash column chromatography on silica gel (eluent: hexane/AcOEt = 20:1) to give the ester 3 (581 mg, $84 \%)$ as a colorless oil.

${ }^{1} \mathrm{H}$ NMR (300 MHz, CDCl $)$ $)$ 6.35-6.27 (1H, m), 6.12-6.03 (1H, m), 5.84-5.63 (2H, m), 4.76 (2H, d, $J$ = 6.9 Hz), 2.79-2.74 (2H, m), 2.48-2.45 (2H, m), 2.05 (3H, s), $1.77(3 \mathrm{H}, \mathrm{d}, J=6.6 \mathrm{~Hz}) ;{ }^{13} \mathrm{C}$ NMR $(75$ $\left.\mathrm{MHz}, \mathrm{CDCl}_{3}\right) \delta$ 209.3, 165.0, 154.1, 147.1, 135.4, 131.6, 130.1, 122.8, 65.5, 33.8, 26.4, 18.1, 9.9; IR (neat) 2929, 1700, $1447 \mathrm{~cm}^{-1}$; MS (EI) $\mathrm{m} / \mathrm{z} 220\left(\mathrm{M}^{+}\right)$; HRMS (EI) calcd for $\mathrm{C}_{13} \mathrm{H}_{16} \mathrm{O}_{3}\left(\mathrm{M}^{+}\right)$220.1100, found 220.1095 .

6,6a-Dimethyl-3,3a,6,6a,8,9-hexahydro-1H,7H-indeno[3a,4-c]furan-1,7-dione (4). A stainless sealed tube including a solution of the ester $3(25.0 \mathrm{mg}, 0.114 \mathrm{mmol})$ and BHT (2.5 $\mathrm{mg}, 0.0114 \mathrm{mmol})$ in toluene $(1.1 \mathrm{~mL})$ was heated at $180{ }^{\circ} \mathrm{C}$ for $24 \mathrm{~h}$. After removal of the solvent in vacuo, the residue was purified by flash column chromatography on silica gel (eluent: hexane/AcOEt $=5: 1$ ) to give the lactone 4 (23.0 mg, 91\%) as a white solid. 
${ }^{1} \mathrm{H}$ NMR (400 MHz, $\left.\mathrm{CDCl}_{3}\right) \delta$ 5.89-5.86 (1H, m), 5.77-5.74 (1H, m), 4.51-4.48 (1H, m), 4.15-4.10 (1H, m), 3.11-3.05 (1H, m), 2.39-2.31 (1H, m), 2.16-2.01 (3H, m), 1.87-1.82 (1H, m), 1.21 (3H, s), 0.99 (3H, d, $J=7.8 \mathrm{~Hz}) ;{ }^{13} \mathrm{C}$ NMR (100 MHz, $\left.\mathrm{CDCl}_{3}\right) \delta 217.0,176.5,136.5,123.1,67.6,54.2,52.3,40.3,39.9$, 34.3, 23.1, 17.8, 17.1; IR (neat) 2978, 1757, $1734 \mathrm{~cm}^{-1}$; MS (EI) m/z $220\left(\mathrm{M}^{+}\right.$); HRMS (EI) calcd for $\mathrm{C}_{13} \mathrm{H}_{16} \mathrm{O}_{3}\left(\mathrm{M}^{+}\right)$220.1100, found 220.1092; Mp 141-143 ${ }^{\circ} \mathrm{C}$.

3-Isobutyl-6,6-dimethylcyclohex-2-en-1-one (6). To a stirred solution of 4,4-dimethylcyclohexane-1,3-dione (5.00 g, $35.6 \mathrm{mmol})$ in benzene (100 mL) were added p-TsOH (355 $\mathrm{mg}, 1.86 \mathrm{mmol})$ and $i-\mathrm{BuOH}(6.7 \mathrm{~mL}, 72.5 \mathrm{mmol})$ at room temperature. After reflux with Dean-Stark apparatus for $15 \mathrm{~h}$, the reaction mixture was diluted with $\mathrm{Et}_{2} \mathrm{O}$ and the reaction was quenched with saturated aqueous $\mathrm{NaHCO}_{3}$. The water phase was extracted with $\mathrm{Et}_{2} \mathrm{O}$ and the combined organic extracts were washed with brine, dried over $\mathrm{MgSO}_{4}$, filtered, and concentrated in vacuo. The residue was purified by flash column chromatography on silica gel (eluent: hexane/AcOEt = 3:1) to give the vinylogous ester 6 (5.57 $\mathrm{g}, 80 \%)$ as a pale yellow oil.

${ }^{1} \mathrm{H}$ NMR (300 MHz, $\left.\mathrm{CDCl}_{3}\right) \delta 5.23(1 \mathrm{H}, \mathrm{s}), 3.58(2 \mathrm{H}, \mathrm{d}, J=6.6 \mathrm{~Hz}), 2.43(2 \mathrm{H}, \mathrm{t}, J=5.8 \mathrm{~Hz}), 2.17-2.15$ $(1 \mathrm{H}, \mathrm{m}), 1.80(2 \mathrm{H}, \mathrm{t}, J=6.3 \mathrm{~Hz}), 1.15(6 \mathrm{H}, \mathrm{s}), 0.98(6 \mathrm{H}, \mathrm{d}, J=6.6 \mathrm{~Hz}) ;{ }^{13} \mathrm{C} \mathrm{NMR}\left(75 \mathrm{MHz}, \mathrm{CDCl}_{3}\right) \delta$ 204.2, 175.8, 100.8, 74.4, 39.9, 34.8, 27.5, 26.0, 24.4, 18.9; IR (neat) 1655, $1611 \mathrm{~cm}^{-1}$; HRMS (EI) calcd for $\mathrm{C}_{12} \mathrm{H}_{20} \mathrm{O}_{2}\left(\mathrm{M}^{+}\right)$196.1463, found 196.1463.

(E)-4,4-Dimethyl-3-(prop-1-en-1-yl)cyclohex-2-en-1-one (7). To a stirred suspension of Mg (604 mg, $24.9 \mathrm{mmol})$ in THF (48 mL) was added trans-propenyl bromide (2.1 mL, $24 \mathrm{mmol}$ ) at room temperature and heated at reflux for $1.5 \mathrm{~h}$. To a solution of the vinylogous ester 6 (201 mg, $1.02 \mathrm{mmol}$ ) in THF was added the above Grignard reagent ( $0.5 \mathrm{M}$ in THF, $6.2 \mathrm{~mL}, 3.06 \mathrm{mmol})$ at $0{ }^{\circ} \mathrm{C}$. After stirred for $80 \mathrm{~min}$ at room temperature, $10 \%$ aqueous $\mathrm{HCl}$ was added to the mixture at $0{ }^{\circ} \mathrm{C}$. After stirred for 5 min at the same temperature, the water phase was extracted with $\mathrm{Et}_{2} \mathrm{O}$. The combined organic phases were washed with brine, dried over $\mathrm{MgSO}_{4}$, filtered, and concentrated in vacuo. The residue was purified by flash column chromatography on silica gel (eluent: hexane/AcOEt = 5:1) to give the dienone $7(112 \mathrm{mg}, 66 \%)$ as a pale yellow oil.

${ }^{1} \mathrm{H}$ NMR (300 MHz, CDCl $)$ ) 6.26-6.08 (2H, m), 5.97 (1H, s), 2.43-2.38 (2H, m), 1.85-1.81 (5H, m), $1.16(6 \mathrm{H}, \mathrm{s}) ;{ }^{13} \mathrm{C} \mathrm{NMR}\left(75 \mathrm{MHz}, \mathrm{CDCl}_{3}\right) \delta 199.4,166.3,132.6,127.8,121.5,37.5,34.6,34.3,26.8$, 19.0; IR (neat) $1665 \mathrm{~cm}^{-1}$; MS (EI) $\mathrm{m} / z 164\left(\mathrm{M}^{+}\right)$; HRMS (EI) calcd for $\mathrm{C}_{11} \mathrm{H}_{16} \mathrm{O}\left(\mathrm{M}^{+}\right)$164.1201, found 164.1203.

(E)-4,4-Dimethyl-3-(prop-1-en-1-yl)cyclohex-2-en-1-ol (8). To a stirred solution of the dienone 7 (51.7 mg, $0.314 \mathrm{mmol})$ in $\mathrm{CH}_{2} \mathrm{Cl}_{2}(2.0 \mathrm{~mL})$ was added DIBAL $(1.0 \mathrm{M}$ in toluene, $0.9 \mathrm{~mL}, 0.9 \mathrm{mmol})$ at $0{ }^{\circ} \mathrm{C}$. After stirred for $15 \mathrm{~min}$ at the same temperature, the reaction was quenched with saturated aqueous $\mathrm{NH}_{4} \mathrm{Cl}$ at $0{ }^{\circ} \mathrm{C}$. The filtrate was washed with brine, dried over $\mathrm{Na}_{2} \mathrm{SO}_{4}$, filtered, and concentrated in vacuo. 
The residue was purified by flash column chromatography on silica gel (eluent: hexane/AcOEt $=2: 1$ ) to give the alcohol 8 (50.2 $\mathrm{mg}, 96 \%)$ as a colorless oil.

${ }^{1} \mathrm{H}$ NMR (300 MHz, $\left.\mathrm{CDCl}_{3}\right) \delta 5.96(1 \mathrm{H}, \mathrm{d}, J=15.3 \mathrm{~Hz}), 5.89-5.80(1 \mathrm{H}, \mathrm{m}), 5.65(1 \mathrm{H}, \mathrm{d}, J=3.3 \mathrm{~Hz})$, 4.18 (1H, br s), 1.92-1.84 (1H, m), 1.74 (3H, d, $J=6.3$ Hz), 1.60-1.38 (4H, m), 1.06 (3H, s), 1.00 (3H, s); ${ }^{13} \mathrm{C} \mathrm{NMR} \mathrm{(75} \mathrm{MHz,} \mathrm{CDCl}_{3}$ ) $\delta$ 147.0, 129.4, 126.1, 123.1, 66.7, 35.6, 33.7, 29.0, 28.0, 27.8, 18.5; IR (neat) $3329 \mathrm{~cm}^{-1}$; MS (EI) m/z $166\left(\mathrm{M}^{+}\right)$; HRMS (EI) calcd for $\mathrm{C}_{11} \mathrm{H}_{18} \mathrm{O}\left(\mathrm{M}^{+}\right)$166.1358, found 166.1380.

(E)-4,4-Dimethyl-3-(prop-1-en-1-yl)cyclohex-2-en-1-yl-2-methyl-3-oxo-cyclopent-1-ene-1-carboxyl-

ate (9). To a solution of carboxylic acid $2 \mathbf{b}(108 \mathrm{mg}, 0.774 \mathrm{mmol})$ and alcohol (82.7 $\mathrm{mg}, 0.497 \mathrm{mmol})$ in $\mathrm{CH}_{2} \mathrm{Cl}_{2}(5.0 \mathrm{~mL})$ were added EDCI $(195 \mathrm{mg}, 1.02 \mathrm{mmol})$ and $\mathrm{HOBt} \cdot \mathrm{H}_{2} \mathrm{O}(30.4 \mathrm{mg}, 0.249 \mathrm{mmol})$ at room temperature. After stirred for $35 \mathrm{~min}$, the mixture was diluted with $\mathrm{CH}_{2} \mathrm{Cl}_{2}$ and the organic phase was washed with saturated aqueous $\mathrm{NaHCO}_{3}$ and $10 \%$ aqueous citric acid, dried over $\mathrm{MgSO}_{4}$, filtered, and concentrated in vacuo. The residue was used for the next reaction without further purification because of instability against column chromatography on silica gel.

${ }^{1} \mathrm{H}$ NMR (300 MHz, $\left.\mathrm{CDCl}_{3}\right) \delta 5.96(1 \mathrm{H}, \mathrm{d}, J=16.5 \mathrm{~Hz}), 5.93-5.82(1 \mathrm{H}, \mathrm{m}), 5.69(1 \mathrm{H}, \mathrm{d}, J=3.8 \mathrm{~Hz})$, $5.42(1 \mathrm{H}, \mathrm{q}, J=4.7 \mathrm{~Hz}), 2.79-2.73$ (2H, m), 2.47-2.44 (2H, m), 2.03 (3H, s), 2.00-1.92 (1H, m), 1.83$1.78(1 \mathrm{H}, \mathrm{m}), 1.75$ (3H, d, $J=6.1 \mathrm{~Hz}), 1.71-1.63$ (1H, m), 1.58-1.46 (1H, m), 1.10 (3H, s), 1.03 (3H, s); ${ }^{13} \mathrm{C}$ NMR $\left(75 \mathrm{MHz}, \mathrm{CDCl}_{3}\right) \delta$ 209.7, 165.1, 154.9, 149.7, 128.8, 127.1, 117.6, 70.3, 35.1, 33.8, 33.5, 27.9, 27.3, 26.4, 25.1, 18.4, 9.9; IR (neat) 1713, 1645, $1570 \mathrm{~cm}^{-1}$; MS (EI) m/z $288\left(\mathrm{M}^{+}\right.$); HRMS (EI) calcd for $\mathrm{C}_{18} \mathrm{H}_{24} \mathrm{O}_{3}\left(\mathrm{M}^{+}\right)$288.1726, found 288.1753.

\section{8,8,10,10a-Tetramethyl-2,3,5a,6,7,8,10,10a-octahydro-4H-cyclopenta[7,8]naphtha-[1,8-bc]furan-1,4(} 3a1H)-dione (10a and 10b). A stainless sealed tube including a solution of the ester 9 (30.2 $\mathrm{mg}, 0.104$ $\mathrm{mmol})$ in xylene $(0.9 \mathrm{~mL})$ was heated at $145^{\circ} \mathrm{C}$ for $18 \mathrm{~h}$. After removal of the solvent in vacuo, the residue was purified by flash column chromatography on silica gel (eluent: hexane/AcOEt $=4: 1$ ) to give the lactones 10a (16.0 mg, colorless prism, 53\%) and 10b (5.9 mg, pale yellow prism, 20\%).

10a: ${ }^{1} \mathrm{H}$ NMR (300 MHz, $\left.\mathrm{CDCl}_{3}\right) \delta 5.43(1 \mathrm{H}, \mathrm{t}, J=2.5 \mathrm{~Hz}), 4.70-4.62(1 \mathrm{H}, \mathrm{m}), 3.14(1 \mathrm{H}, \mathrm{d}, J=8.5 \mathrm{~Hz})$, 2.48-2.34 (1H, m), 2.15-1.99 (1H, m), 1.96-1.88 (4H, m), 1.64-1.52 (3H, m), 1.20 (6H, s), 1.15 (3H, s), $1.01(3 \mathrm{H}, \mathrm{d}, J=7.6 \mathrm{~Hz}) ;{ }^{13} \mathrm{C} \mathrm{NMR}\left(75 \mathrm{MHz}, \mathrm{CDCl}_{3}\right) \delta 217.4,176.6,146.9,128.2,77.0$, 56.4, 53.2, 43.0, 42.4, 36.4, 34.9, 33.6, 32.5, 29.5, 29.4, 26.0, 18.0, 16.5; IR (neat) 1761, $1734 \mathrm{~cm}^{-1}$; MS (EI) m/z 288 $\left(\mathrm{M}^{+}\right)$; HMRS (EI) calcd for $\mathrm{C}_{18} \mathrm{H}_{24} \mathrm{O}_{3}\left(\mathrm{M}^{+}\right)$288.1726, found 288.1758; Mp 175-177 ${ }^{\circ} \mathrm{C}$.

10b: 1H NMR (300 MHz, $\left.\mathrm{CDCl}_{3}\right) \delta 5.47(1 \mathrm{H}, \mathrm{t}, J=3.0 \mathrm{~Hz}), 4.72-4.65(1 \mathrm{H}, \mathrm{m}), 2.77-2.64(2 \mathrm{H}, \mathrm{m})$, 2.49-2.27 (3H, m), 2.19-2.11 (1H, m), 2.08-2.01 (1H, m), 1.63-1.48 (2H, m), 1.35-1.29 (1H, m), 1.12 (6H, s), 1.01 (3H, s), 0.98 (3H, d, $J=7.1 \mathrm{~Hz}) ;{ }^{13} \mathrm{C}$ NMR $\left(75 \mathrm{MHz}, \mathrm{CDCl}_{3}\right) \delta 216.0,178.8,138.8,126.3$, 76.7, 53.2, 52.6, 41.6, 34.6, 34.5, 33.2, 31.4, 29.8, 28.8, 25.7, 16.6, 14.1; IR (neat) $1750 \mathrm{~cm}^{-1}$; MS (EI) $\mathrm{m} / \mathrm{z} 288\left(\mathrm{M}^{+}\right)$; HRMS (EI) calcd for $\mathrm{C}_{18} \mathrm{H}_{24} \mathrm{O}_{3}\left(\mathrm{M}^{+}\right)$288.1726, found 288.1699; Mp 156-158 ${ }^{\circ} \mathrm{C}$. 
Deposition number CCDC-1421053 for compound 10a. Free copies of the data can be obtained via http://www.ccdc.cam.ac.uk/conts/retrieving.html (or from the Cambridge Crystallographic Data Centre, 12 Union Road, Cambridge, CB2 1EZ, UK; Fax: +44 1223 336033; e-mail: deposit@ccdc.cam.ac.uk).

\section{REFERENCES (AND NOTES)}

1. H. Nemoto and K. Fukumoto, Tetrahedron, 1998, 54, 5425.

2. Selected examples; (a) V. Jeso, C. Aquino, X. Cheng, H. Mizoguchi, M. Nakashige, and G. C. Micalizio, J. Am. Chem. Soc., 2014, 136, 8209; (b) W. H. Kim, J. H. Lee, and S. J. Danishefsky, J. Am. Chem. Soc., 2009, 131, 12576; (c) N. Kotoku, Y. Sumii, T. Hayashi, and M. Kobayashi, Tetrahedron Lett., 2008, 49, 7078; (d) C. C. Browder and F. G. West, Synlett, 1999, 1363; (e) M. Ihara, S. Suzuki, N. Taniguchi, K. Fukumoto, and C. Kabuto, J. Chem. Soc., Chem. Commun., 1991, 1168.

3. (a) N. Azzi, E. Griffen, M. Light, and B. Linclau, Chem. Commun., 2006, 4909; (b) S. A. Selkälä and A. M. Koskinen, Eur. J. Org. Chem., 2005, 1620; (c) G. Zhou, Q.-Y. Hu, and E. J. Corey, Org. Lett., 2003, 5, 3979; (d) H. Urabe, K. Kusaka, D. Suzuki, and F. Sato, Tetrahedron Lett., 2002, 43, 285; (e) K. Ishihara, H. Kurihara, M. Matsumoto, and H. Yamamoto, J. Am. Chem. Soc., 1998, 120, 6920; (f) K. A. Parker and T. Iqbal, J. Org. Chem., 1987, 52, 1620; (g) M. E. Jung and K. M. Halweg, Tetrahedron Lett., 1984, 25, 2121.

4. (a) R. Munakata, H. Katakai, T. Ueki, J. Kurosaka, K.-I. Takao, and K.-I. Tadano, J. Am. Chem. Soc., 2004, 126, 11254; (b) M. F. Hossain, R. N. Yadav, S. Mondal, A. Jana, and S. Ghosh, Tetrahedron, 2013, 69, 7956; (c) D. F. Taber and Y. Song, J. Org. Chem., 1996, 61, 7508.

5. (a) K. L. Handore, B. Seetharamsingh, and D. S. Reddy, J. Org. Chem., 2013, 78, 8149; (b) M. E. Jung and D. Yoo, Org. Lett., 2011, 13, 2698; (c) W. H. Kim, J. H. Lee, B. Aussedat, and S. J. Danishefsky, Tetrahedron, 2010, 66, 6391; (d) A. Chrobok, E. Gössinger, R. Kalb, E. Orglmeister, and J. Schwaiger, Tetrahedron, 2007, 63, 8326; (e) F. Fringuelli, F. Pizzo, A. Taticchi, T. D. J. Halls, and E. Wenkert, J. Org. Chem., 1982, 47, 5056.

6. Recent reports on cis-hydrindane synthesis except using Diels-Alder reaction; (a) G. Liu, G. Mei, R. Chen, H. Yuan, Z. Yang, and C.-C. Li, Org. Lett., 2014, 16, 4380; (b) T. J. K. Findley, D. Sucunza, L. C. Miller, D. T. Davies, and D. J. Procter, Chem. Eur. J., 2008, 14, 6862.

7. (a) V. Benesova, V. Herout, and F. Sorm, Collect. Czech. Chem. Commun., 1969, 34, 1810; (b) V. Benesova, Z. Samek, V. Herout, and F. Sorm, Collect. Czech. Chem. Commun., 1969, 34, 582.

8. H. Nawa, Proc. Japan Acad., 1951, 27, 436.

9. (a) R. Thomas, P. Gray, and J. Andrew, Adv. Drug Res., 1990, 19, 312; (b) P. S. Steyn and F. R. 
Heerden, Nat. Prod. Rep., 1998, 397.

10. (a) K. Shiomi, R. Uchida, J. Inokoshi, H. Tanaka, Y. Iwai, and S. Omura, Tetrahedron Lett., 1996, 37, 1265; (b) S. Omura, J. Inokoshi, R. Uchida, K. Shiomi, R. Masuma, T. Kawakubo, H. Tanaka, Y. Iwai, S. Kosemura, and S. Yamamura, J. Antibiot., 1996, 49, 414; (c) R. Uchida, K. Shiomi, J. Inokoshi, T. Sunazuka, H. Tanaka, Y. Iwai, H. Takayanagi, and S. Omura, J. Antibiot., 1996, 49, 418.

11. (a) M. E. Jung and M. Guzaev, Org. Lett., 2012, 14, 5169; (b) M. E. Jung, D. Ho, and H. V. Chu, Org. Lett., 2005, 7, 1649; (c) M. E. Jung and P. Davidov, Angew. Chem. Int. Ed., 2002, 41, 4125; (d) J. M. Eagan, M. Hori, J. Wu, K. S. Kanyiva, and S. A. Snyder, Angew. Chem. Int. Ed., 2015, 54, 7842; (e) R. Baker, D. L. Selwood, C. J. Swain, N. M. H. Webster, and J. Hirshfield, J. Chem. Soc., Perkin Trans. 1, 1988, 471.

12. For preparation, see Supporting Information.

13. Y. Tobe, J.-I. Sato, T. Sorori, K. Kakiuchi, and Y. Odaira, Tetrahedron Lett., 1986, 27, 2905.

14. Similar intramolecular Diels-Alder reaction of carbon-tethered substrates to form carbocyclic products have been reported, see: M. Ihara, A. Kawaguchi, H. Ueda, M. Chihiro, and K. Fukumoto, J. Chem. Soc., Perkin Trans. 1, 1987, 1331.

15. R. P. Gandhi, B. Vig, and S. M. Mukherji, J. Indian Chem. Soc., 1959, 36, 299.

16. CCDC 1421053 includes the crystallographic data for this manuscript. 